Hydrol. Earth Syst. Sci., 17, 1035-1050, 2013

www.hydrol-earth-syst-sci.net/17/1035/2013/

doi:10.5194/hess-17-1035-2013

(C) Author(s) 2013. CC Attribution 3.0 License.

\title{
Stable water isotope variation in a Central Andean watershed dominated by glacier and snowmelt
}

\author{
N. Ohlanders ${ }^{1}$, M. Rodriguez ${ }^{1}$, and J. McPhee ${ }^{1,2}$ \\ ${ }^{1}$ Department of Civil Engineering, Faculty of Physical and Mathematical Sciences, Universidad de Chile, Santiago, Chile \\ ${ }^{2}$ Advanced Mining Technology Centre (AMTC), Faculty of Physical and Mathematical Sciences, Universidad de Chile, \\ Santiago, Chile
}

Correspondence to: N. Ohlanders (nvidar@ing.uchile.cl)

Received: 2 October 2012 - Published in Hydrol. Earth Syst. Sci. Discuss.: 30 October 2012

Revised: 30 January 2013 - Accepted: 18 February 2013 - Published: 7 March 2013

\begin{abstract}
Central Chile is an economically important region for which water supply is dependent on snow- and ice melt. Nevertheless, the relative contribution of water supplied by each of those two sources remains largely unknown. This study represents the first attempt to estimate the region's water balance using stable isotopes of water in streamflow and its sources. Isotopic ratios of both $\mathrm{H}$ and $\mathrm{O}$ were monitored during one year in a high-altitude basin with a moderate glacier cover $(11.5 \%)$. We found that the steep altitude gradient of the studied catchment caused a corresponding gradient in snowpack isotopic composition and that this spatial variation had a profound effect on the temporal evolution of streamflow isotopic composition during snowmelt. Glacier melt and snowmelt contributions to streamflow in the studied basin were determined using a quantitative analysis of the isotopic composition of streamflow and its sources, resulting in a glacier melt contribution of $50-90 \%$ for the unusually dry melt year of 2011/2012. This suggests that in (La Niña) years with little precipitation, glacier melt is an important water source for central Chile. Predicted decreases in glacier melt due to global warming may therefore have a negative long-term impact on water availability in the Central Andes. The pronounced seasonal pattern in streamflow isotope composition and its close relation to the variability in snow cover and discharge presents a potentially powerful tool to relate discharge variability in mountainous, melt-dominated catchments with related factors such as contributions of sources to streamflow and snowmelt transit times.
\end{abstract}

\section{Introduction}

\subsection{Hydrology in the extratropical Andes region - unknown inputs}

Knowledge of the processes determining discharge in catchments dominated by glacier melt and snowmelt becomes increasingly important as population and industrial activity increase in regions dependent on these water sources. Approximately one sixth of the global population derives much of its water from such melt-dominated watersheds (Barnett et al., 2005; Lemke et al., 2007). A region where meltwater availability is especially important is the central part of Chile, which houses much of the country's growing economic production (Cai et al., 2003). Meteorological and hydrological conditions are similar to many semi-arid, mountainous regions of the world; extremely low precipitation during the summer months results in snowmelt and glacier melt from high altitudes being the main sources of streamflow (Cortés et al., 2011; Garreaud et al., 2009; Pellicciotti et al., 2005).

Globally, climate change has been projected to cause major changes in glacier (Huss et al., 2008; Huss, 2011; Pellicciotti et al., 2010; Viviroli et al., 2011) and snow- (Graham, 2004; Jeelani et al., 2012; McCarthy et al., 2001) melt contributions to streamflow. So far, the processes governing accumulation and melt of snow and ice at high elevations in the extratropical Andes remain difficult to quantify and model. Although it is probably true that melt from the seasonal snowpack accounts for the bulk of runoff in the region (Masiokas et al., 2006; Peña and Nazarala, 1987), the contribution of glacier melt to the hydrologic regime remains a key component of the hydrologic cycle considering that (1) many 
high altitude catchments in the region have a relatively large percentage of glacier cover and (2) total annual precipitation shows high inter-annual variability, meaning that in dry years ("La Niña" periods with a low air surface pressure in the western Pacific; Garreaud et al., 2009), snowmelt could be reduced by as much as $50 \%$ compared to an average year. Another factor that makes it hard to analyse discharge patterns in extra-tropical, Andean catchments is that the lag between melt and discharge of snowmelt water is relatively long. Typically, snowmelt peaks during October or November in high altitude basins, whereas discharge peaks in December or January (Cortés et al., 2011). This might partly be due to a much later peak in the other main water source, glacier melt, which normally peaks in mid- to late summer (February-March for the Southern Hemisphere, Jost et al., 2012; Ragettli and Pellicciotti, 2012).

Isotopic studies of runoff and its sources have a large potential to shed light on these unknowns as stable isotopes of water are natural tracers with potentially different compositions of snow- and glacier melt (Cable et al., 2011). The combined measurement of isotopic ratios of oxygen and hydrogen is especially powerful since the co-variation between the two in meteoric water sources can be affected by evaporation, sublimation, remelting and exchange with atmospheric vapour (Ingraham, 1998).

\subsection{Isotopic variability in snowmelt and glacier melt}

The stable isotope composition of river water is determined firstly by the conditions causing rain- and snowfall (mainly air temperature at the time of precipitation; Ingraham, 1998; Rozanski and Araguás, 1995) and secondly by evaporation and mixing during (subsurface) transport through catchments (Barnes and Turner, 1998).

During the last few decades, isotopic signatures of stream water have successfully been analysed to determine the source of stream water. Such studies have mostly focused on determining the proportions of "pre-event" and "event" water (e.g. Bottomley et al., 1984; Dincer et al., 1970). A large number of studies have also estimated snowmelt contribution to discharge (e.g. Laudon and Slaymaker, 1997; Laudon, 2004; Mast et al., 1995). However, few studies have fully recognised the large spatial and temporal variation in the isotopic signal of snowmelt. Taylor et al. (2001) presented the isotopic composition of meltwater in four different climates, and showed that snowmelt became isotopically heavier as the melt season progressed. This was due to preferential melt of lighter water molecules, i.e. ${ }^{16} \mathrm{O}$ and ${ }^{1} \mathrm{H}$ are preferentially released into the higher phase (meltwater is initially more isotopically depleted than to the remaining snowpack), a process that is analogue to fractionation during evaporation (Cooper et al., 1993; Rodhe, 1998). This process, from here on referred to as isotopic elution, causes enrichment (increase in $\delta^{18} \mathrm{O}$ and $\delta^{2} \mathrm{H}$ ) through time in snowmelt and depletion in the remaining snowpack. Isotopic enrichment during snowmelt, often within a depletion rate of $4-8 \%$ o $\delta^{18} \mathrm{O}$, has been observed in a few different studies (Taylor et al., 2001; Unnikrishna et al., 2002; Cooper et al., 1993).

None of the above mentioned studies considered that the isotopic signal of streamflow is also affected by the spatial distribution of the snowpack and by snowmelt flowpaths (variation in transit time and flow route). In larger basins with much altitude variation, it should be assumed that for any given time, meltwater leaving the snowpack at different elevations is the result of different stages of snowmelt. For example, at a given time during snowmelt, an isotopically depleted signal from early-stage meltwater at high altitudes in streamflow might be compensated by isotopically enriched meltwater from low altitudes where snowmelt is in a later stage. Further, in large basins with a high elevation range, the average isotopic composition of the snowpack changes with altitude. The progressive isotopic depletion of precipitation with elevation is exacerbated by increased fractionation between liquid and vapour at low temperatures (Ingraham, 1998).

Rozanski and Araguás (1995) presented stable water isotope data for precipitation in large parts of South America. For the Andean region at $33^{\circ} \mathrm{S}$ (where our study catchment is located), they showed that the snow pack was depleted in heavy isotopes with increasing altitude. The slope was steepest at around $1500 \mathrm{~m}\left(0.6 \% \circ \delta^{18} \mathrm{O} / 100 \mathrm{~m}\right)$ and substantially flatter at $2000-4000 \mathrm{~m}(0.2 \% / 100 \mathrm{~m})$. As a comparison, Siegenthaler and Oeschger (1980) reported a 0.32 decrease in $\delta^{18} \mathrm{O}$ per $100 \mathrm{~m}$ increase in elevation for the Swiss Alps.

Few studies have recognised the effect of such an altitude gradient on the isotopic variation in streamflow. As a working hypothesis for this research, we assumed that in catchments with large altitude ranges, spatial variation in the isotopic composition of the snowpack (causing streamflow to become isotopically lighter through time due to snowmelt originating from higher elevations) will affect the isotopic composition of stream water, and that this effect is at least as large as the often observed isotopic elution phenomenon (causing streamflow to be isotopically heavier through time as snowmelt isotopic elution progresses).

\subsection{Study objectives}

The overarching goal of this study was to analyse the isotopic composition of streamflow in a high altitude basin and to estimate the contribution of the main sources comprising discharge during major periods throughout a hydrologic year. Furthermore, we aimed to explore how episodic changes in isotope composition, along with meteorological and discharge data, can be combined to understand the hydrological processes occurring in semi-arid mountainous catchments, such as groundwater storage and precipitation events. 


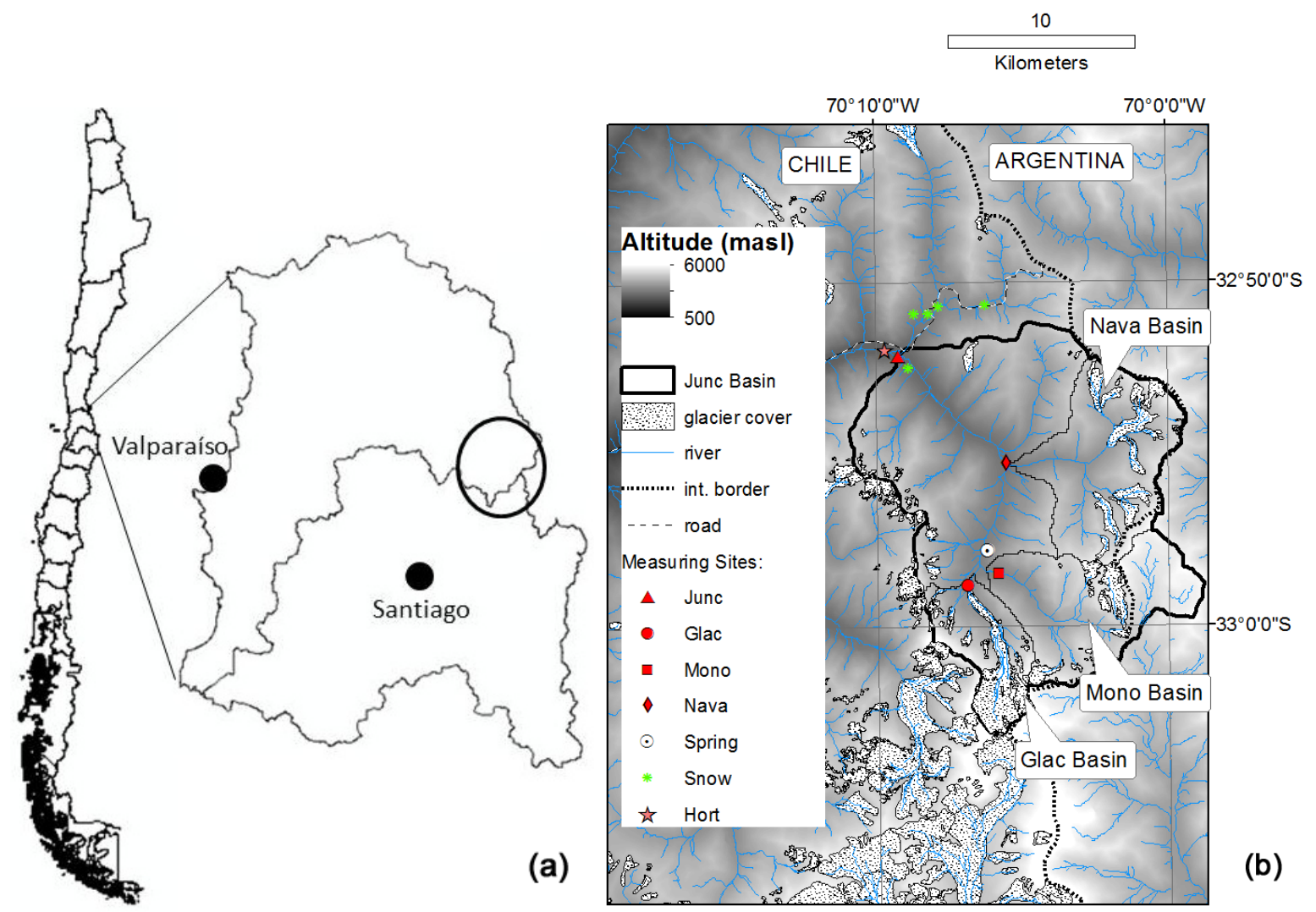

Fig. 1. (a-b) Study area with locations of sampling points. Junc= Juncal River sampling site and discharge gauge. Glac/Mono/Nava = sampling site for tributaries (the Glac headwater represents glacier melt). Spring $=$ sampled spring. Snow $=$ Altitude gradient of snow samples. Hort $=$ Hornitos meteorological station.

\section{Study area, data and methodology}

\subsection{Study site description}

The Juncal River basin (Junc), comprises $256 \mathrm{~km}^{2}$ of alpine, largely unvegetated terrain with an altitude range of 2200-5900 m a.s.1. (Fig. 1b). A sparse cover of predominantly low shrubs and meadows only occurs in the valley bottoms. The catchment is located in the Aconcagua basin in the region of Valparaiso, central Chile (Fig. 1a). The Juncal River is fed by three major tributaries, the glacial river to the south, originating in the Juncal Norte glacier, the Monos de Agua River to the southeast and the Navarro River to the east. The sub-catchments defined by these river nodes/sampling points are referred to as Glac Basin, Mono Basin and Nava Basin, respectively (Fig. 1). The southern and eastern parts of Junc Basin are located at higher altitudes, and contain most of the watershed's $11.5 \%$ glacier cover. Figure 2 shows hypsometric curves for the Junc Basin and its sub-basins. It can be seen that for the Mono Basin and the Glac Basin much more of the area is located at high altitudes compared to the total catchment (Junc Basin), whereas Nava Basin has an intermediate altitude distribution. Mono Basin has the highest

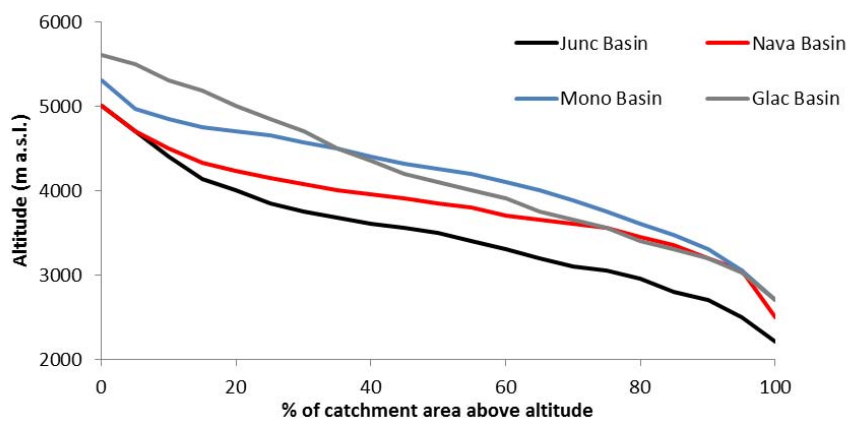

Fig. 2. Hypsometric curves for Junl Basin and the three main subcatchments (Nava Basin, Mono Basin and Glac Basin).

percentage of the area located at altitudes between 3500 and $4500 \mathrm{~m}$ a.s.l., whereas Glac Basin has the highest percentage of very high ( $>4500 \mathrm{~m}$ a.s.l.) altitudes. The Juncal Norte glacier covers $10 \mathrm{~km}^{2}$, and because of its dominant importance in terms of ice volume it was chosen for measurements of glacier melt. Figure $1 \mathrm{~b}$ shows that the Juncal Norte glacier represents the largest continuous ice cover in the catchment.

The studied catchment experiences a Mediterranean, near semi-arid climate with an extreme concentration of 


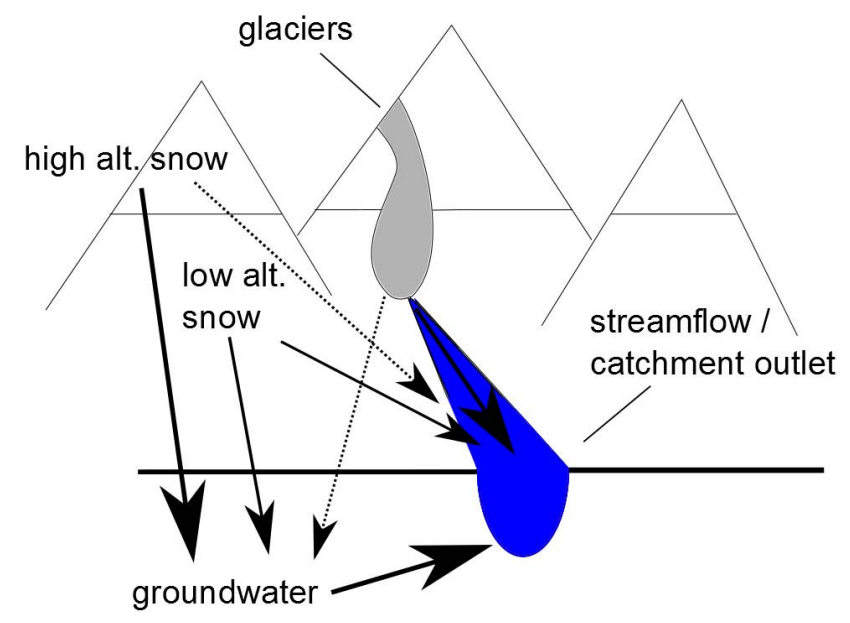

Fig. 3. Hypothesised flowpaths in the studied catchment. Thicker arrows indicates more important flowpaths. alt. $=$ altitude

precipitation during the winter months (Pellicciotti et al., 2005). Seasons are defined here as winter (June-August), spring (September-November), summer (DecemberFebruary) and autumn (March-May).The warmest six months (October-March) are dominated by clear weather and high incoming radiation. Most precipitation (especially $>2000$ m.a.s.l.) is in solid form, because precipitation occurs almost exclusively during the cold season. At high altitudes, liquid precipitation occurs only during occasional convective storms (Garreaud et al., 2009). Low relative humidity throughout the year results in large differences between daily minimum and maximum temperatures (typically $\approx 10^{\circ} \mathrm{C}$ ). At Junc, average temperatures in summer are $\sim+15^{\circ} \mathrm{C}$ and in winter $\sim+2^{\circ} \mathrm{C}$. Precipitation shows a very strong interannual variability, influenced by the quasi-decadal ENSO sea surface temperature patterns (Pellicciotti et al., 2005; Rubio-Álvarez and McPhee, 2010; Waylen and Poveda, 1990). Maximum snow accumulation is determined on the one hand by orographic lift causing increased precipitation on the windward slope of the Andes and on the other hand by steeper slopes and stronger winds near the crest causing less accumulation. This trade-off results in a precipitation maximum at around $3000 \mathrm{~m}$ a.s.l. on the windward slope of the Andes, below the crest, as is usually observed over high mountain ranges around the world. At higher altitudes and on leeside snow depth decreases sharply (Viale and Nuñez, 2011).

Figure 3 summarises the hypothesised flowpaths in the catchment. The glacial headwaters probably transports most glacier melt directly to streamflow as the rapid meltwater meet densely packed headwater riverbeds. Low-altitude snow that melts in spring, often travels as overland flow and via melt channels in the snowpack, probably reaching the main river quicker than high altitude snow that melts in summer.

\subsection{Streamflow monitoring and meteorological data}

Standard hydrometeorological data was available from a network of stations operated by the Dirección General de Aguas (the Chilean water agency; DGA). These data include daily streamflow at Junc, plus daily precipitation measured at the Riecillos meteorological station $\left(32^{\circ} 55^{\prime} 22 \mathrm{~S}\right.$, $70^{\circ} 21^{\prime} 19 \mathrm{~W}, 1290 \mathrm{ma}$ a.s.l.) and daily air temperature plus snow accumulation measured with a snow pillow at the Portillo station $\left(32^{\circ} 50^{\prime} 43 \mathrm{~S}, 70^{\circ} 06^{\prime} 38 \mathrm{~W}, 3000 \mathrm{~m}\right.$ a.s.l.). Additionally, meteorological data (air temperature, relative humidity, and solar radiation) were obtained from the Hornitos weather station (Hort), operated by the Mountain Hydrology Group at the Department of Civil Engineering, Universidad de Chile (Fig. 1b). All data was collected and verified for a study period comprising an entire water year, from 30 April 2011 to 24 April 2012.

\subsection{MODIS SCA data}

Daily snow covered area (SCA) data was obtained from satellite data supplied by the Moderate Resultion Imaging Spectroradiometer (MODIS) instrument aboard the TERRA satellite (LP DAAC, 2012.). The data is downloadable from the NASA Reverb website and supplies information of snow and cloud cover on a $500 \mathrm{~m}$ grid. Days with a high cloudcover, as well as sporadic snowfall events $(<3$ days of snow cover) were removed from the data set with the gaps being filled by linear interpolation.

\subsection{Isotopic sampling and analysis}

An overview of the sampling protocol is provided in Table 1. Samples from the Juncal River were collected at Hort, ca. $200 \mathrm{~m}$ downstream from the DGA discharge gauge at Junc (Fig. 1). During the period of high discharge (5 October 2011 to 25 March 2012), samples were collected at either 24- or 48-h intervals, at 17:00 LT, using a TELEDYNE ISCO 6712 automatic water sampler. Additionally, on 3-4 April 2012, samples were collected at 3-h intervals in order to determine diurnal isotopic variation. A thin layer of mineral oil was added to all collection bottles in order to prevent evaporation from affecting the isotopic composition of the sampled water (Gazis and Feng, 2004). Manual stream samples were collected at least every three weeks, during the low flow season (September-April 2011) as well as to complement the automatic sampling during the high flow season (Table 1).

Manual samples were filtered in the field using a $0.45 \mu \mathrm{m}$ paper filter and stored in $15 \mathrm{~mL}$ plastic bottles without headspace. Upon returning to the University of Chile, samples were stored overnight at $+6^{\circ} \mathrm{C}$. The following day, mineral oil and sediments were removed from the automatic samples, also using $0.45 \mu \mathrm{m}$ paper filters. Samples were then poured into in $15 \mathrm{~mL}$ plastic vials and stored without 
Table 1. Overview of all samples collected in the study.

\begin{tabular}{|c|c|c|c|c|c|c|c|c|c|c|c|c|c|}
\hline \multirow[b]{2}{*}{ Sample Type } & \multicolumn{2}{|c|}{ Autumn } & \multicolumn{3}{|c|}{ Winter } & \multicolumn{3}{|c|}{ Spring } & \multicolumn{3}{|c|}{ Summer } & \multicolumn{2}{|c|}{ Autumn } \\
\hline & $\begin{array}{c}\text { Apr } \\
2011\end{array}$ & $\begin{array}{l}\text { May } \\
2011\end{array}$ & $\begin{array}{c}\text { Jun } \\
2011\end{array}$ & $\begin{array}{c}\text { Jul } \\
2011\end{array}$ & $\begin{array}{l}\text { Aug } \\
2011\end{array}$ & $\begin{array}{l}\text { Sep } \\
2011\end{array}$ & $\begin{array}{c}\text { Oct } \\
2011\end{array}$ & $\begin{array}{l}\text { Nov } \\
2011\end{array}$ & $\begin{array}{l}\text { Dec } \\
2011\end{array}$ & $\begin{array}{c}\text { Jan } \\
2012\end{array}$ & $\begin{array}{l}\text { Feb } \\
2012\end{array}$ & $\begin{array}{l}\text { Mar } \\
2012\end{array}$ & $\begin{array}{c}\text { Apr } \\
2012\end{array}$ \\
\hline Glac & 1 & 1 & - & - & - & - & 1 & 1 & - & 2 & - & 1 & 2 \\
\hline Mono & 1 & 1 & - & - & - & - & 1 & 1 & - & 1 & - & - & 1 \\
\hline Nava & 1 & - & & & & & 1 & 1 & - & 1 & & 1 & 2 \\
\hline Spring & - & - & - & - & - & - & - & - & - & 1 & - & 1 & 1 \\
\hline Rain & - & - & - & - & - & 2 & 2 & 2 & - & 2 & - & 1 & 1 \\
\hline $\begin{array}{l}\text { Snow cores } \\
\text { (altitude gradient) }\end{array}$ & - & - & - & - & 10 & - & - & - & - & - & - & - & - \\
\hline $\begin{array}{l}\text { Snow cores } \\
(2200 \mathrm{~m} \text { a.s.1.) }\end{array}$ & - & - & - & - & 10 & - & - & - & - & - & - & - & - \\
\hline Snowmelt & - & - & - & - & - & 2 & - & - & - & - & - & - & - \\
\hline Junc manual & 1 & 1 & 1 & 2 & 3 & 2 & 3 & 2 & 1 & 2 & - & - & 2 \\
\hline Junc (auto) & & & & & (con & ously & 24-ol & $48 \mathrm{~h} \mathrm{i}$ & rvals) & & & & \\
\hline
\end{tabular}

headspace at $+6^{\circ} \mathrm{C}$ until they were shipped to the Ehleringer lab in Utah, USA for isotopic analysis. We tested the effect of the added mineral oil layer by adding this fluid to samples of known isotopic composition and then immediately filtering and analysing those samples. Differences in both $\delta^{18} \mathrm{O}$ and $\delta^{2} \mathrm{H}$ before and after mineral oil addition were insignificant $(p<0.05)$. The same conclusion was made by Gazis and Feng (2004).

A limited number of samples, evenly distributed throughout the year, were collected at the basin headwaters (Table 1) because of limited accessibility and safety concerns (which prevented the installation of an automatic sampler). A total of nine samples of glacier melt were collected at the snout of the Juncal Norte glacier (Glac), while the outlets of the Monos de Agua (Mono) and Navarro (Nava) tributaries were sampled on six and seven occasions, respectively.

Water seeping out of the ground at a single location ("Spring", $2750 \mathrm{~m}$ a.s.l., Fig. 1) was sampled three times. This spring delivered a stable flow of water with a high electric conductivity throughout the year $\left(>800 \mu \mathrm{S} \mathrm{cm}^{-1}\right.$ which was in the high range of measurements at Junc) and therefore probably represents relatively long-term aquifer storage.

Snow was sampled using a $2 \mathrm{~m}$-length, $4.5 \mathrm{~cm}$-diameter PVC tube in order to get a core representative of the total snowpack depth. The tube was gently pushed down through the snowpack until it reached the ground. The snow around the sampling tube was removed, and the sample was removed whilst covering the bottom of the tube with a gloved hand and then placed in triple plastic bags. When transported back to the field station, the samples were packed tightly together with cold water samples and were not allowed to melt. At the research station, the samples were melted overnight at $7^{\circ} \mathrm{C}$, upon which filtration was carried out as with stream water samples.
In order to test our assumption regarding the altitudinal variation in the snowpack and melt isotopic composition, two snowmelt samples were collected at each $200 \mathrm{~m}$ elevation increment between 2200 and $3000 \mathrm{~m}$ a.s.l. on 10 August 2011, following the road to the Argentinean border from the Portillo snow pillow (3000 m a.s.l.) to Juncal River (2200 ma.s.l.). The range of elevations at which snow could be sampled was limited by the goal of obtaining all samples within the same day. A more complete representation of the catchments' snowpack is the subject of future work. On 4 August 2011, 10 samples were collected along a micro-scale gradient (ca. $20 \mathrm{~m}$ apart) at Junc (2200 m a.s.1.). Finally on 13 and 21 September 2011, direct samples of melting snow were collected at Junc by placing a $3 \times 3 \mathrm{~m}$ plastic sheet underneath the snowpack, from which snowmelt was funnelled into a collecting bottle. These samples represented the isotopic composition of snowmelt at a late stage of melt, because at the catchment outlet little snow (depth $<50 \mathrm{~cm}$ ) remained on this date.

Rain samples were collected near the stream gauge (at 2200 m a.s.l., see Fig. 1) in a plastic bottle with a funnel with coarse filter paper. A thin layer of mineral oil was added before each collection, to prevent evaporation affecting the isotopic ratios of the collected rain water.

All water samples were analysed for oxygen and hydrogen stable isotopes using laser spectroscopy (Los Gatos model 908-0008 OA-ICOS analyser), at the isotope facility at Ehleringer lab, Department of Biology, University of Utah, USA. This is a relatively new technique, with excellent results both in term of robustness and accuracy (Lis et al., 2008; Penna et al., 2010, 2012). The standard deviation of 10 lab replicates was $1.1 \%$ for $\delta^{2} \mathrm{H}$ and $0.1 \%$ for $\delta^{18} \mathrm{O}$. The accuracy was $0.69 \%$ or $\delta^{2} \mathrm{H}$ and $0.11 \%$ for $\delta^{18} \mathrm{O}$. Analysis of 6 field replicates (Nava samples collected immediately after each other) showed a standard deviation similar to that 
of the lab replicates, $1.22 \%$ for $\delta^{2} \mathrm{H}$ and $0.14 \%$ for $\delta^{18} \mathrm{O}$ suggesting that the sampling routine introduced little error to our data set.

\section{Results and discussion}

\subsection{Meteorological characterization of the study period}

For simplicity, in this paper we refer to years in which maximum snow water equivalent (SWE) at the Portillo snow pillow was $\leq 0.5 \mathrm{~m}$ and $\geq 1.0 \mathrm{~m}$ as "dry" and "wet" years, respectively. Rainfall and discharge data show that the year of study was unusually dry. Based on precipitation records from the Riecillos station, the probability of exceedence of precipitation during the winter of 2011 was $85 \%$ (only 12 of $79 \mathrm{yr}$ of record had less precipitation than 2011) and in 11 of 44 "melt years" (October-September) discharge from Junc was smaller than in 2011/2012 (i.e. a probability of exceedence of $75 \%$ for streamflow).

\subsection{Water balance estimates from historic runoff and meteorological data}

In order to visualise the approximate contribution of snowmelt to runoff compared to glacier melt, we plotted maximum winter SWE measured at the snow pillow at Portillo, against area-specific runoff from the Juncal River measured at Junc (Fig. 4). For each point the X-axis represents the maximum SWE of a specific year and the y-axis shows runoff in the following "melt year" (October-September). Figure 4 shows that there is a good correlation between maximum SWE and Juncal river runoff ( $p<0.001$ ), indicating (as expected) that annual snow input determines total runoff volume. However, the relationship has a large intercept on the $\mathrm{x}$-axis; ca. $0.5 \mathrm{~m}$ of specific runoff. If we assume that summer rain contributes only a small percentage of streamflow, it seems likely that glacier melt and deep groundwater with a long residence time comprises nearly all runoff (ca. $0.5 \mathrm{~m}$ ) in dry years. In years of higher precipitation, glacier melt may be reduced due to a longer period of snow cover. However, Huss et al. (2008) showed, for long-term data sets, that standard deviations of runoff from basins dominated by glacier melt were $<15 \%$. Assuming that total glacier melt volume does not change drastically between years, Fig. 4 further suggests that in average years (i.e. at average spec. runoff; $0.84 \mathrm{~m}$ ), glacier melt still is the dominant source, whereas in wet years, snowmelt contributes approximately half of runoff (rain and deep groundwater contributions were excluded in this estimation). Water mass balance results produced by the distributed hydrological model TOPKAPI (Ragletti and Pellicciotti, 2012) for the same catchment, suggested as much as $80 \%$ of snowmelt contribution to runoff for $2005 / 2006$, which was a wet year. These contrasting estimates illustrate the uncertainties in the water balance of glacierised catchments in the region.

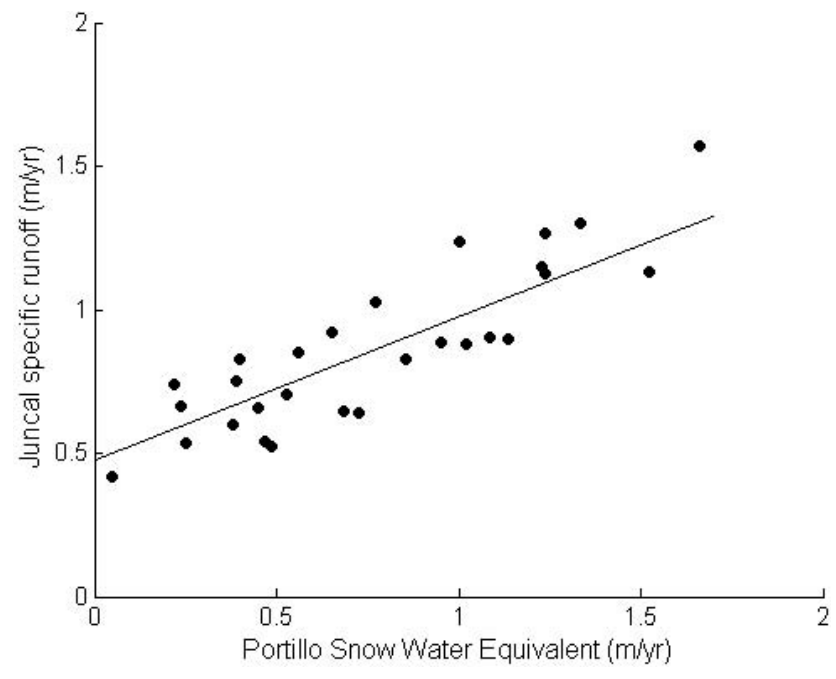

Fig. 4. Juncal River total annual specific runoff (October year $x$ to September year $x+1$ ) plotted against maximum winter Snow Water Equivalent at the Portillo meteorological station in each corresponding year $(x)$. Data for 28 yr between 1970 and 2009 is presented.

Figure 5 shows Juncal River discharge for four years with different snow accumulation. The inserted table shows (spring and summer) runoff and precipitation data for the same years. It is evident from Fig. 5 that streamflow in wet years has a different seasonal pattern, where discharge is high throughout the summer. The increase starts in early summer, assumingly at a point where soils are near-saturated with snowmelt waters, causing large volumes of stored meltwaters to leave the catchment. In the two dry years, discharge in summer stayed at a moderate level. Taking into account the conclusions from Fig. 4 above, we assume that in dry years, glacier melt and, possibly, sporadic rainfall events or deep groundwater comprise the main controls of discharge variability throughout the summer season. It could be noted here that since most precipitation occurs in winter and intense rainstorms mostly occur in mid-to-late summer (JanuaryFebruary), the rain-on-snow effect is less likely to be an important factor forcing snowmelt, compared to basins in more humid regions.

\subsection{Stable isotope composition of river sources}

Table 2 shows the average isotopic composition of all sample types. Snow samples at low $\left(\delta^{2} \mathrm{H}=-120.6 \%\right.$ ) and mid- $\left(\delta^{2} \mathrm{H}=-133.6 \%\right.$ o elevation show that snow can be more enriched as well as more depleted than Junc streamflow $\left(\delta^{2} \mathrm{H}=-127.3 \% \circ\right)$. Glacier melt $\left(\delta^{2} \mathrm{H}=-130.8 \%\right.$ o $)$ was more depleted than streamflow but more enriched than mid-latitude snow.

Figure $6 \mathrm{a}-\mathrm{b}$ shows the isotopic composition of the snow cores as a function of altitude. Elevation significantly controls snowpack isotope composition. A relationship is especially evident for elevations between $2600-3000 \mathrm{~m}$, although 


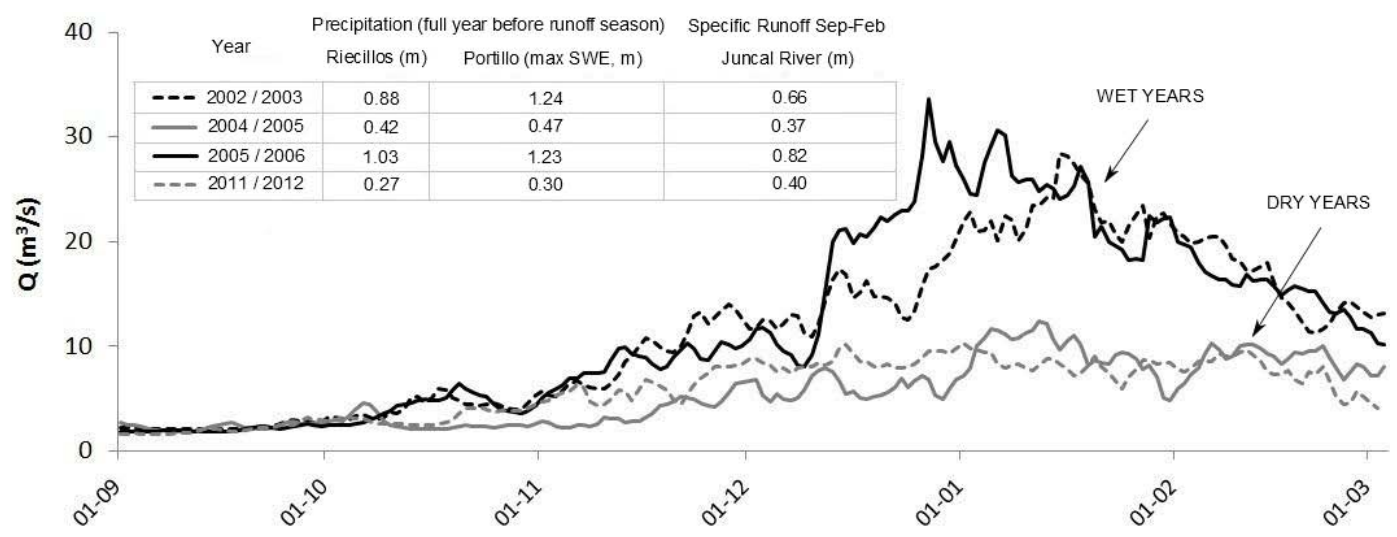

Fig. 5. Juncal discharge in two wet and two dry years. The inserted table shows precipitation data and cumulative discharge for the same example years.

Table 2. Average $\delta^{2} \mathrm{H}$ and $\delta^{18} \mathrm{O}$ in all sample types with standard deviations.

\begin{tabular}{lrrrrrrrrr}
\hline & Junc & Glac & Rain & $\begin{array}{r}\text { Snow 10 Aug average } \\
\text { for 2200-2600 m }\end{array}$ & $\begin{array}{r}\text { Snow 10 Aug average } \\
\text { for 2600-3000 m }\end{array}$ & $\begin{array}{r}\text { Snow 4 Aug } \\
(2200 \mathrm{~m})\end{array}$ & Spring & Mono & Nava \\
\hline$n$ samples & 127 & 9 & 10 & 6 & 6 & 10 & 2 & 6 \\
Average $\delta^{2} \mathrm{H}(\% \circ)$ & -127.3 & -130.8 & -74.4 & -120.6 & -133.6 & -110.2 & -133.8 & -136.0 & -126.8 \\
St. Dev. $\delta^{2} \mathrm{H}(\% \circ)$ & $(1.6)$ & $(2.6)$ & $(52.0)$ & $(7.4)$ & $(12.0)$ & $(4.4)$ & $(0.0)$ & $(1.8)$ & $(1.2)$ \\
Average $\delta^{18} \mathrm{O}(\% \circ)$ & -17.26 & -17.92 & -10.91 & -16.24 & -17.94 & -15.23 & -18.06 & -18.32 & -17.11 \\
St. Dev. $\delta^{18} \mathrm{O}(\% \circ)$ & $(0.29)$ & $(0.38)$ & $(6.6)$ & $(0.87)$ & $(1.45)$ & $(0.66)$ & $(0.12)$ & $(0.35)$ & $(0.23)$ \\
Ratio $\delta^{18} \mathrm{O} \delta^{2} \mathrm{H}$ & 0.136 & 0.137 & 0.147 & 0.135 & 0.134 & 0.138 & 0.135 & 0.135 & 0.135 \\
\hline
\end{tabular}

if the regression line is drawn along those points, two of the low-altitude samples would be outliers. It is indeed possible that the two more depleted low-altitude samples should be removed from the data set because partial snowmelt occurs regularly on warm, sunny winter days at altitudes $<2500 \mathrm{~m}$ a.s.1. These lower values may therefore have been caused by meltwater entering the sample sites from surrounding hill slopes. Overall, the relation between altitude and isotope composition of precipitation was similar to that presented by Rozanski and Araguás (1995) who sampled precipitation and small rivers in Chile and Argentina. In our study, the average depletion with altitude was $0.44 \% \circ \delta^{18} \mathrm{O} / 100 \mathrm{~m}$, or $0.56 \% \circ \delta^{18} \mathrm{O} / 100 \mathrm{~m}$ if the two most depleted low-altitude samples are treated as outliers and removed. Because there is still some uncertainty about the relationship between altitude and the isotope composition of snow, we prefer to use two categories: low (2200-2600 ma.s.l.) and mid(2600-3000 m a.s.1.) altitude samples when discussing the influence of snowmelt on streamflow composition. The terms low- and mid-altitude refer to the catchment's altitude range; high altitudes $(>3000 \mathrm{~m})$ were not sampled due to logistical limitations (see Sect. 2.4).

The lower diagram in Fig. 7 shows the isotopic composition of the collected snow and rain samples. Rain (white circles) had an extremely wide range of isotopic compositions, from highly enriched precipitation that fell at high temperatures during summer and late spring, to isotopically depleted precipitation which fell at near-zero temperatures, therefore clustering with the snow samples. The two upper-right corner snow samples correspond to snowmelt collected in a late stage of melt. These were the two most enriched samples, demonstrating the often-observed effect that the later part of melt from a snowpack is isotopically heavier than early melt. This shows that temporal isotopic change of snowmelt, i.e. isotopic elution, did occur. However, the large variation in $2200 \mathrm{~m}$ snow core samples, taken at various locations before the initiation of snowmelt, and the large difference between the two $2400 \mathrm{~m}$ samples (which were located less than $50 \mathrm{~m}$ apart) shows that micro-scale spatial variation in snowpack composition might be as large as isotopic elution during snowmelt. In our data set therefore, the altitudinal gradient was the dominant and most definable source of variation in the snowpack (see correlations between altitude and isotope composition in Fig. 6).

The isotopic composition of glacier melt (white triangles in the upper, magnified diagram of Fig. 7) shows relatively little variation, considering that samples were collected at regular intervals throughout the year. All glacier samples had an isotopic composition similar to the two snow samples from $2800 \mathrm{~m}$ a.s.l., which is the elevation of the glacier tongue. The glaciers' accumulation zone is presently located $>3000 \mathrm{~m}$ a.s.l. For a given altitude therefore, glacier melt appears to have a more enriched isotopic signal than snowmelt. The more depleted signal compared to snow at the same 

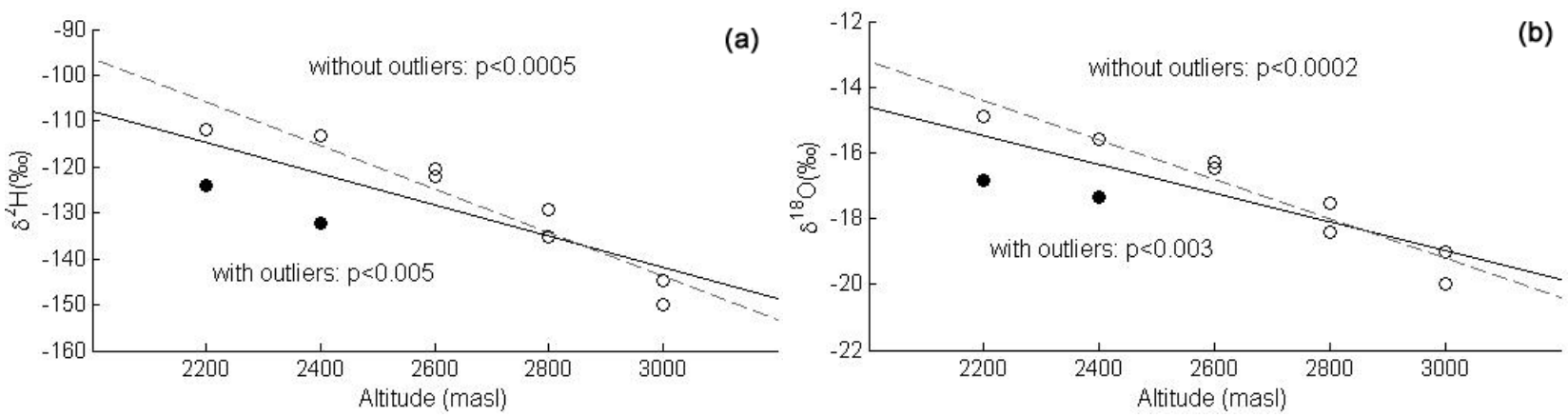

Fig. 6. (a-b) Relationship between $\delta^{2} \mathrm{H}$ (a) and $\delta^{18} \mathrm{O}$ (b) and altitude of snow-cores collected along an elevation gradient (2200-3000 m a.s.1.), along the road to the Chile-Argentina border, just northeast of the studied catchment $\left(\delta^{2} \mathrm{H}=0.0342 \cdot\right.$ elevation -39.48 $r^{2}=0.66 \delta^{18} \mathrm{O}=0.0044 \cdot$ elevation $\left.-5.8765 r^{2}=0.70\right)$. In an alternative correlation (dashed line), black points were treated as outliers and removed $\left(\delta^{2} \mathrm{H}=0.0475 \cdot\right.$ elevation $-1.28 r^{2}=0.90 \delta^{18} \mathrm{O}=0.0060 \cdot$ elevation $\left.-1.23 r^{2}=0.92\right)$

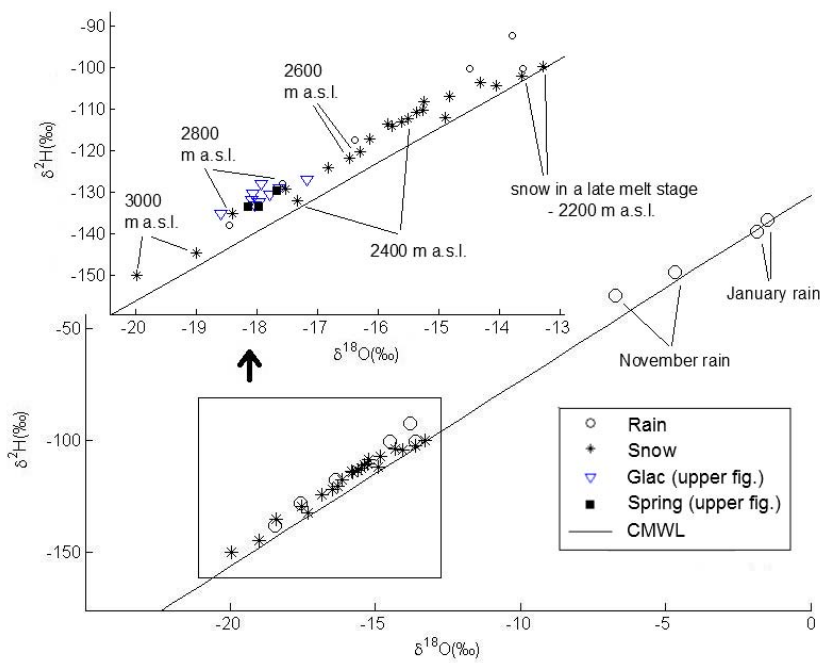

Fig. 7. Isotopic composition in samples of glacier melt, rain, snow and a spring in the study area. The upper diagram magnifies the data which had values within the range of snow samples and includes the nine glacier melt (Glac) samples (blue, open triangles) and the three spring samples (black squares). The altitudes at which snow samples (black stars) were collected are also shown. The samples for which no altitude is shown were collected near the stream gauge (at $2200 \mathrm{~m}$ a.s.1.). CMWL is a line representing the $\delta^{18} \mathrm{O} / \delta^{2} \mathrm{H}$ relationship defined as the Chilean Meteoric Water Line $\left(\delta^{2} \mathrm{H}=8.3 \cdot \delta^{18} \mathrm{O}+9.8\right.$; Spangenberg et al., 2007)

altitude suggested that measurements at Glac were representative for glacier melt (at least from the Juncal Norte glacier) and little affected by snowmelt. Further, depleted isotopic values were not observed during periods of intense snowmelt at high altitudes (the lowest value, $\delta^{2} \mathrm{H}=-135.1 \%$, was observed in autumn on 30 April).

Soil water ("Spring") samples had an isotopic composition similar to that of Glac and mid-altitude snow, suggesting that soil water was little affected by isotopic fractionation, due to evaporation.

The isotopic composition of glacier samples, compared to the altitude gradient found in snow isotope composition has important implications for the interpretation of streamflow sources. When air temperature rises in early spring, snowmelt is expected to start in the lower part of the catchment, resulting in meltwater with a relatively enriched isotopic signal that is clearly different from glacier melt (mean glacier $\delta^{2} \mathrm{H}=-130.8 \%$, mean $2200-2600 \mathrm{~m}$ snow $\delta^{2} \mathrm{H}=-120.6 \%$ o). However, when snowmelt water is dominated by snow from higher altitudes, the snowmelt signal (mean 2600-3000 m snow $\delta^{2} \mathrm{H}=-133.6 \%$ ) may be almost identical to, or even more depleted than, glacier melt.

The Chilean Meteoric Water Line (CMWL, Fig. 7) was determined from isotope data of precipitation at different latitudes (Coyhaique, $45^{\circ} 21^{\prime} 00 \mathrm{~S}$, Puerto Mont, $41^{\circ} 28^{\prime} 12 \mathrm{~S}$, Punta Arenas, $53^{\circ} 00^{\prime} 00 \mathrm{~S}$ and Santiago, $33^{\circ} 27^{\prime} 00 \mathrm{~S}$; Spangenberg et al., 2007). Most samples had a similar deviation from the relationship between $\delta^{2} \mathrm{H}$ and $\delta^{18} \mathrm{O}$ described by the CMWL. Therefore, $\delta^{18} \mathrm{O} / \delta^{2} \mathrm{H}$ ratios do not seem to be a valuable indicator for attempting source separation (see ratios in Table 2). The most notable deviations were found in the late melt snow samples and summer (Jan) rain samples which were relatively lower in $\delta^{2} \mathrm{H}$ compared to $\delta^{18} \mathrm{O}$. The study site's location on the northern edge of the region described by the CMWL probably explains the difference between this line and a best-fit line for our samples.

\subsection{Juncal River isotopic variation}

\subsubsection{Seasonal pattern}

Figure 8 shows all Junc samples, sorted by season, as well as all samples from the glacier (Glac) and Monos de Agua (Mono) tributary. Nava samples are not shown in the graph but had an average isotopic composition similar to that of 


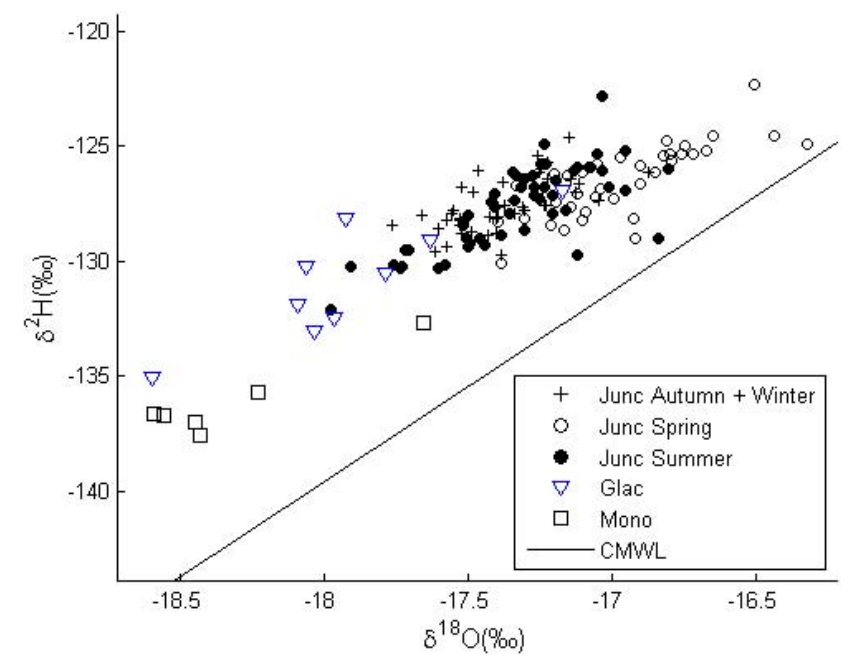

Fig. 8. Isotopic composition of water samples from the Juncal River (Junc) and from the glacier (Glac) and Monos de Agua (Mono) tributaries. Junc samples are grouped by season; autumn = March-May, winter $=$ June-August, spring $=$ September-November, $\quad$ summer $=$ December-February. CMWL is a line representing the $\delta^{18} \mathrm{O} / \delta^{2} \mathrm{H}$ relationship defined as the Chilean Meteoric Water Line $\left(\delta^{2} \mathrm{H}=8.3 \cdot \delta^{18} \mathrm{O}+9.8\right.$; Spangenberg et al., 2007)

Junc. The average (positive or negative) difference for samples collected at Junc and Nava on the same day was only $1.24 \%$ or $\delta^{2} \mathrm{H}$ and $0.25 \%$ for $\delta^{18} \mathrm{O}$. The Mono Basin has a high average altitude and a substantial glacier cover $(15 \%)$, but much lower than that of the Glac Basin (42\%). It can be seen that most Mono samples were more depleted than Glac samples, probably because of more snowmelt occurring at altitudes $>3500 \mathrm{~m}$ a.s.l. compared to glacier melt (see hypsometric curves in Fig. 2). Junc samples all have values between the low- and mid-altitude snow samples. Most spring samples cluster towards the low-altitude snow samples and most summer samples cluster towards the mid-altitude snow and glacier (Glac) samples (cf. Fig. 7). It can be seen that Junc samples collected in summer and (especially) autumn and winter are more depleted in $\delta^{18} \mathrm{O}$ relative to $\delta^{2} \mathrm{H}$ compared to those collected in spring. This may be an effect of a longer residence time within the catchment, because it has been shown that mineral weathering reactions can cause a shift in the $\delta^{18} \mathrm{O} / \delta^{2} \mathrm{H}$ relationship (Clark and Fritz, 1997).

The time series of $\delta^{2} \mathrm{H}$ in the Juncal River during the entire sampling period is displayed in Fig. 9a along with discharge, catchment snow covered area, precipitation and air temperature (the two latter recorded at Hort, Fig. 1b). Average $\delta^{2} \mathrm{H}$ of snow at low (2200-2600 m) and mid (2600-3000 m) altitudes are shown as lines and the two standard deviations around the average glacier signal are shown as a hatched "belt" in Fig. 9a. The temporal change in $\delta^{18} \mathrm{O}$ is not presented in this figure as this data series showed a very similar pattern to that of $\delta^{2} \mathrm{H}$. Figure $9 \mathrm{~b}$ shows the time series of both isotopic signals, plotted along with with discharge. It should be noted that precipitation data is from the lowest part of the catchment (Junc) where rainfall occurs less frequently than in the upper parts of the catchment.

With the exception of episodic peaks in $\delta^{2} \mathrm{H}$ (more isotopically enriched water), the main patterns in Junc $\delta^{2} \mathrm{H}$ variation were accompanied by changes in discharge. The isotope data in fact mirrors discharge data on a seasonal scale: $\delta^{2} \mathrm{H}$ decreased when $Q$ increased (October-December), then slowly increased (with the exception of episodic high values) towards a winter "baseline" as streamflow dropped towards winter baseflow (January-April). The decreasing trend in $\delta^{2} \mathrm{H}$ from $-122.3 \%$ on 15 October to $-132.1 \%$ on 15 December was accompanied by a decrease of the snowpack as shown by the SCA data, which changes from 80 to $0 \%$ within the same time period. The similar timing of (1) decrease in SCA, (2) increase in discharge from low winter levels to the first of two $\left(>10 \mathrm{~m}^{3} \mathrm{~s}^{1}\right)$ peaks and (3) distinct decrease in $\delta^{2} \mathrm{H}$ from the highest to the lowest observed value, suggests that the $\delta^{2} \mathrm{H}$ decrease was a result of streamflow being dominated first by melt of snow from lower altitudes and then progressively by higher-altitude snowmelt and/or glacier melt. Such an evolution of stream sources was expected but its signature in the isotope tracer was more pronounced than anticipated. The day-to-day variation in $\delta^{2} \mathrm{H}$ at Junc was sometimes very large, with some peaks being especially prominent. These peaks were most probably the result of episodic summer rain storms - rain during warm periods was highly enriched in $\delta^{2} \mathrm{H}$ (Fig. 7) and even small volumes of rainwater could therefore have caused these peaks. For example, the sharp increase in $\delta^{2} \mathrm{H}$ on 6 January $(-123 \%$ ) coincided with a thunderstorm which caused intense rainfall on 5 January $(9.4 \mathrm{~mm}$ in $3 \mathrm{~h}$ at Hort).

The highest $\delta^{2} \mathrm{H}$ value (most isotopically enriched stream water), on 15 October, coincided with a local peak in SCA, just before rapid snowmelt started, as well as rainfall (snowfall above $2700 \mathrm{~m}$ a.s.1.), low temperatures and a flattening in the discharge curve, just after flow had started to increase. This peak in $\delta^{2} \mathrm{H}(-121 \%$ o) was partly due to rainfall (although rain fell at temperatures near zero: daily mean $=0.5^{\circ} \mathrm{C}$ at Hort) and partly a result of accumulated snowmelt from the first two weeks of melt in the lowest parts of the catchment. From this point, $\delta^{2} \mathrm{H} \%$ o decreased along a line towards the low value on 15 December, with exceptional peaks that were probably caused by rainfall, such as that which occurred on 20 November (only $1.6 \mathrm{~mm}$ of rain according to Hort data, but probably much more at high altitudes). Importantly, the dip in $\delta^{2} \mathrm{H}$ is very close to the average glacier $\delta^{2} \mathrm{H}$ signal, but does not reach the line indicating mid-altitude snow and is much more enriched than snow from $>3000 \mathrm{~m}$. On 15 December 2011, the snow line had been above $3700 \mathrm{~m}$ a.s.l. for more than a month. Even if transit times were long, it is therefore very unlikely that snowmelt reaching the stream at this point in time came from altitudes $<3000 \mathrm{~m}$. Therefore, at this and all later sampling 


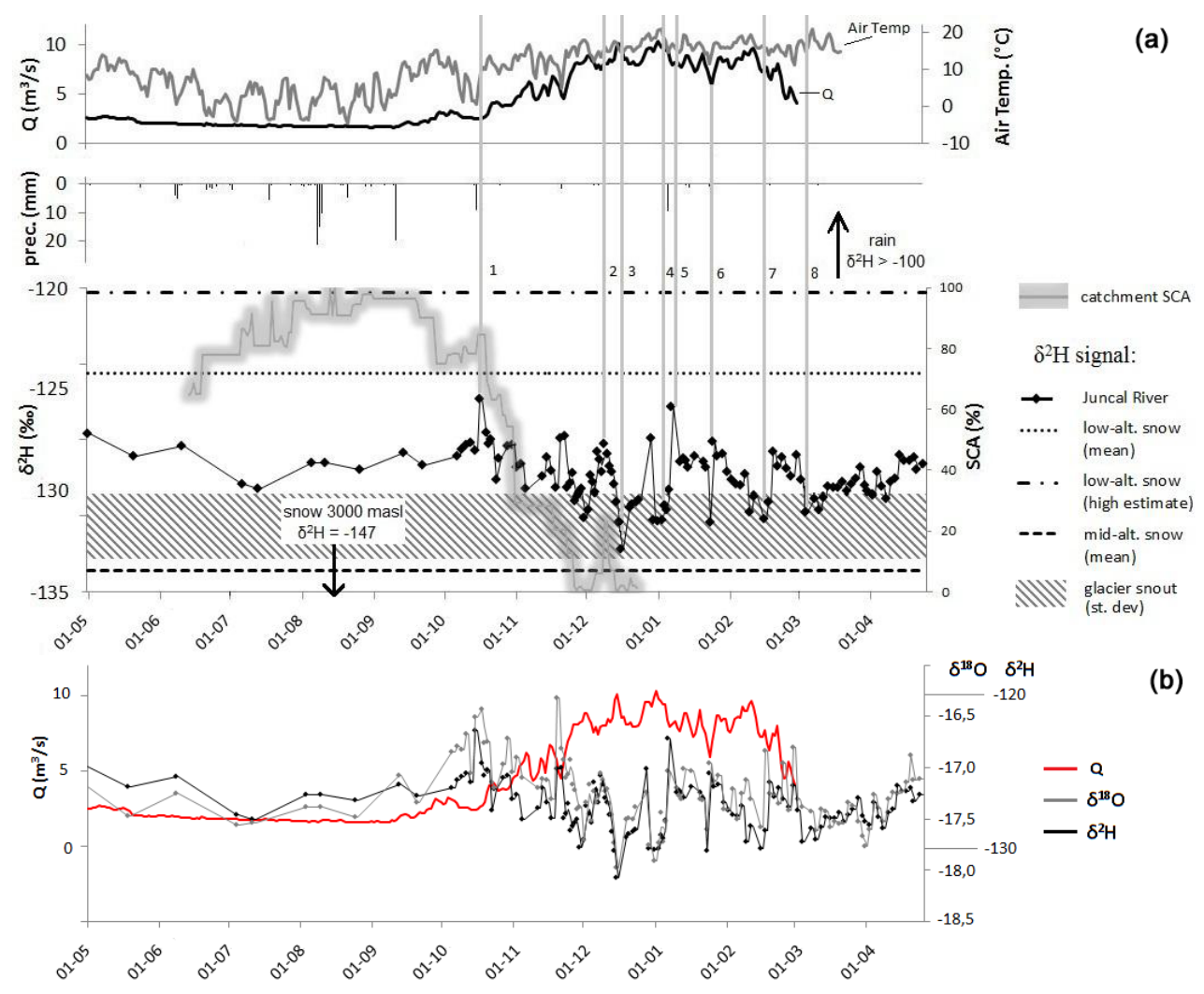

Fig. 9. (a) Temporal variation in $\delta^{2} \mathrm{H}$ in the Juncal River during the study period (May 2012-April 2012), with average values for low(2200-2600) and mid- (2600-300) altitude snow and standard deviation of glacier melt. The figure also shows catchment SCA and discharge, precipitation and air temperature at Hort. (b) Temporal variation in $\delta^{2} \mathrm{H}$ and $\delta^{18} \mathrm{O}$ during the study period, along with discharge in the Juncal River.

points streamflow was likely dominated by glacier melt. After the dip in $\delta^{2} \mathrm{H}(-132.1 \%$ on 15 December $)$, the data set becomes highly variable, the lowest values staying within the reach of glacier melt, while the majority of points form episodes of periodically increasing "waves" of isotopically much more enriched water. It appears most likely that during this summer period, glacier melt was the main source of runoff, the signal being frequently interrupted by warm rainfall which was probably not important in terms of water volume (rainy days did not affect $Q$ ), but had a pronounced effect on streamflow $\delta^{2} \mathrm{H}$ due to rainfall being extremely enriched in ${ }^{2} \mathrm{H}$. If the peaks caused by rainfall events are excluded, it can be seen for the January-April $\delta^{2} \mathrm{H}$ data that as the hydrograph slowly recedes, the low range data points slowly increase towards winter values, which are relatively stable at around $-126 \%$. This was interpreted as streamflow changing from being dominated by glacier melt to groundwater. During winter, discharge was continuously low (Fig. 9) and decreased slowly until the first days of spring snowmelt, pointing towards a winter hydrologic regime controlled by slowly depleting groundwater, consisting of a mix of glacier melt and snow and rain from a variation of altitudes.

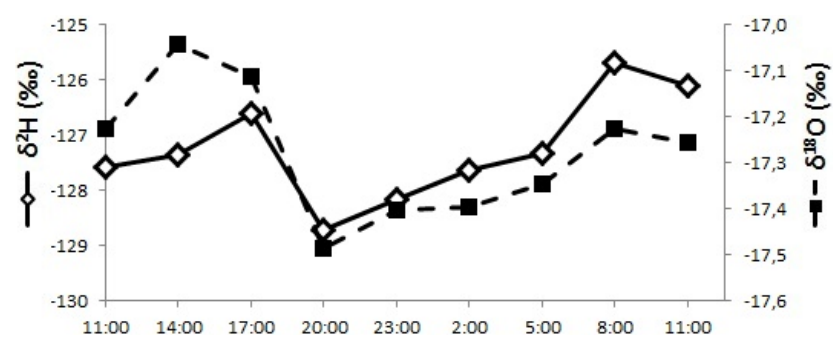

Fig. 10. Variation in $\delta^{2} \mathrm{H}$ and $\delta^{18} \mathrm{O}$ during $24 \mathrm{~h}$ in the Juncal River. Samples were taken every three hours between 11:00 LT (3 April) and 11:00 LT (4 April) 2012.

\subsubsection{Episodic variability}

Numbered, vertical lines in Fig. 9a point out episodes demonstrating how $\delta^{2} \mathrm{H}$ responded to a selection of interesting precipitation, discharge and SCA data points. At line 1, low-altitude snow and rain initiated the melt period as described above. In the episodic $\delta^{2} \mathrm{H}$ peak at line 2 , air temperature dropped and new snow covered the upper part of the catchment (see SCA data). The relatively high $\delta^{2} \mathrm{H}$ was caused by snow from lower altitudes dominating streamflow 
composition as melt halted in the upper catchment, and possibly also by rainfall. The lowest observed $\delta^{2} \mathrm{H}$ value, at line 3 , occurred just after the first $\left(>10 \mathrm{~m}^{3} \mathrm{~s}^{-1}\right)$ peak in discharge. This was most likely the last significant influence of midand high-altitude snowmelt, before glacier melt became the dominant source. The second discharge peak at line 4 is accompanied by a peak in temperature and is followed by a few $\delta^{2} \mathrm{H}$ points near the average glacier melt signal. Possibly, snow cover on large parts of the glacier surface was lost during the first peak in $Q$ (line 3), causing highly enhanced glacier melt between line 3 and line 4 . The $\delta^{2} \mathrm{H}$ peak at line 5 was most likely caused by the rainfall that occurred a few days earlier. From here on until line 7 (marking the end of the main summer period) the enrichment effect of summer rains gradually decreased. However, during a cold snap at line 6 , glacier melt was possibly temporarily diminished, increasing the contribution of rain and/or groundwater causing an increase in $\delta^{2} \mathrm{H}$. At line 7, discharge from the glacier dropped, causing aquifer and rain waters to push $\delta^{2} \mathrm{H}$ values upwards. At line 8 , air temperature rose, causing $\delta^{2} \mathrm{H}$ to once again drop to a typical glacier signal. At the end of the measurment period (no precipitation and discharge data available), summer finally ended, causing $\delta^{2} \mathrm{H}$ to increase towards values near those observed in winter.

\subsubsection{Diurnal variability}

On 3 April 2012, the auto-sampler was set to collect a sample every $3 \mathrm{~h}$ in order to monitor isotopic variation within a 24-h period of stable, representative weather conditions. Figure 10 demonstrates that both isotopes showed a relatively high degree of variation within $24 \mathrm{~h}$. This variability seemed to be defined by a sinus-shaped curve, peaking during the afternoon on 3 April and at 08:00 LT in the morning on 4 April. The dip in both isotope tracers at 20:00 LT on 3 April probably represents the largest concentration of glacier melt compared to ground water. This is due to the large diurnal difference in temperature and incoming radiation; on clear days air temperature peaks around 15:00 LT, causing glacier melt to peak a few hours later; $Q$ typically peaks between 18:00 LT and 21:00 LT at this time of the year. $\delta^{18} \mathrm{O}$ data implies that isotopic depletion started between 14:00 LT and 17:00 LT, whereas for $\delta^{2} \mathrm{H}$, the switch to more depleted values occurred after 17:00 LT.

Variation within $24 \mathrm{~h}$ probably caused some of the shortterm (day-to-day) variation which can be seen in Fig. 9, although this effect was minimised by collecting all automatic stream samples at the same time each day (17:00 LT). For the 24-h intensive sampling period (3 April-4 April) the volume weighted mean $\delta^{2} \mathrm{H}$ was $-127.4 \%$. The difference between this value and that measured at 17:00 $(-126.6 \%$ o was small compared to other errors introduced to the estimate of streamflow composition.

\subsection{Mass balance estimate using a quantitative analysis of water stable isotope data in streamflow and sources}

The seasonal time series of streamflow isotopic composition was relatively noisy (i.e. had a high short-term variability). However, distinct seasonal patterns in streamflow $\delta^{2} \mathrm{H}$, compared to $\delta^{2} \mathrm{H}$ in its sources, along with discharge, SCA and air temperature data, could be used to estimate the contribution of sources to streamflow. These contributions were compared to mass balance calculations for 15 October and 15 December, combined with our interpretation of seasonal variation in streamflow sources as described in Sect. 3.4.

\subsubsection{April to 14 October 2011}

Slowly decreasing streamflow throughout the winter period suggests that the dominant source to streamflow was groundwater. Groundwater contained a mix of glacier melt, snowmelt, and a small contribution of rain. Our data does not allow for a percentage estimate of each source for this period, during which river flow represented $25 \%$ of annual streamflow. However, occasional discharge measurements during winter confirmed that the glacial tributary (Glac), contributed at least $25 \%$ of winter streamflow at Junc.

\subsubsection{October to 15 December 2011}

During this period, in which runoff represented $24 \%$ of annual streamflow volume, the isotopic signal at Junc changed from being close to the average of low-altitude snow, to being close to the signals of mid-altitude snowmelt and glacier melt, except during rain events, $\delta^{2} \mathrm{H}$ dropped linearly between 15 October and 15 December. For each of these dates, mass balance equations based on isotope data (Eqs. 1 and 2 , respectively) were used to estimate the contribution of snowmelt and glacier melt.

$$
\begin{aligned}
\delta^{2} \mathrm{H}_{\text {stream }}(15 \mathrm{Oct})= & \mathrm{CG} \times \delta^{2} \mathrm{H}_{\text {glacier }}+(1-\mathrm{CG}) \\
& \times \delta^{2} \mathrm{H}_{\text {(low alt. }) \text { snow }} \\
\delta^{2} \mathrm{H}_{\text {stream }}(15 \text { Dec })= & \mathrm{CG} \times \delta^{2} \mathrm{H}_{\text {glacier }}+(1-\mathrm{CG}) \\
& \times \delta^{2} \mathrm{H}_{\text {(mid } / \text { high alt. }) \text { snow }}
\end{aligned}
$$

where $\mathrm{CG}=$ glacier melt contribution to streamflow $(1=$ $100 \%$ contribution).

Table 3 shows glacier melt contributions resulting from the above equations considering alternative definitions of lowand mid-/high-altitude snow: Fig. 6a suggested an alternative correlation between altitude and snow $\delta^{2} \mathrm{H}$, where two points were treated as outliers and removed. Further, as the origin of snow on 15 December was unknown, 3 scenarios for the altitude origin of snow were considered (Table 3$). \delta^{2} \mathrm{H}(-191.3)$ of snow from $4000 \mathrm{~m}$ a.s.l. was calculated from the regression lines shown in Fig. 6a. The scenario with no outliers and 
$4000 \mathrm{~m}$ a.s.l. for mid-/high- altitude snow has an extremely low $\delta^{2} \mathrm{H}(-191.3)$ for mid-/high- altitude snow. In this case, however, the large uncertainty in input isotope composition is of little significance for total glacier contributions as contributions on 15 December already approached $100 \%$ when using the $\delta^{2} \mathrm{H}$ of snow at $3000 \mathrm{~m}$ a.s.l. Consideration of even higher altitudes did not change the result significantly.

Depending on the chosen isotopic composition of snow, Eqs. (1) and (2) resulted in glacier melt contributions of 8-45\% and $62-98 \%$ for 15 October and 15 December, respectively (see alternative scenarios in Table 3 ). In other words, a minimum contribution of glacier melt estimation was therefore $8 \%$ for 15 October and $62 \%$ for 15 December, whereas a maximum contribution was $45 \%$ for 15 October and $98 \%$ for 15 December. As the different scenarios could be considered extreme low and high estimates, respectively, $35-71 \%$ glacier melt contribution (average between the two dates in the low and high contribution scenario, respectively) was considered a reasonable estimate for the total period.

\subsubsection{December 2011 to 14 April 2012}

After 15 December, $\delta^{2} \mathrm{H}$ at Junc was continuously much more enriched than the signal of high altitude snow. The lowest values during this period are located near the average of Glac data. Rain events interrupted this "base-line", causing peaks of highly enriched isotope ratios. Although these enriched values represented most data points in the period, rainfall volumes were probably small as they did not cause any significant increases in streamflow. Our data does not allow for an exact calculation of glacier contribution during this period but indicates that the contribution of snowmelt was small; the increase in $\delta^{2} \mathrm{H}$ after 15 December suggests an average glacier melt contribution that was substantially higher than on that date (when glacier melt already dominated streamflow). Therefore, glacier melt was assumed to comprise at least $62 \%$ of streamflow (inferred from the minimum 15 December glacier contribution) in this high-flow period, which represented $51 \%$ of annual discharge.

\subsubsection{Resulting glacier melt contribution and statistical evaluation}

Table 4 ("Method I" column) summarises glacier melt contribution in each of the above periods. Using a quantitative analysis for defining seasonal and episodic stable isotope patterns in streamflow and comparing these to meteorological and SCA data, we were able to confirm that streamflow was dominated by glacier melt during the majority of the high-flow period $\left(>5 \mathrm{~m}^{3} \mathrm{~s}^{-1}\right)$. The only time when snowmelt dominated streamflow was during spring (October and possibly November). Using our estimations for each period as summarised in Table 4, we conclude that $50-90 \%$ of streamflow was supplied by glacier melt in the studied year.
In order to assure statistical reliability, we also calculated $p<0.05$ confidence intervals for all isotope concentrations used in Eqs. (1) and (2), obtaining new minimum and maximum contributions for 15 October and 15 December, and thereby for each period in Table 4 ("Method II" column). For snow, the confidence interval was calculated for the altitude/snow isotope composition regression line in Fig. 6a that uses all data points, resulting in a margin of error of $5.7 \%$ in snow $\delta^{2} \mathrm{H}$ at any given altitude. The disadvantage with this method is that the uncertainty associated with choosing the correct altitude of the snow source cannot be calculated. For 15 December, $3000 \mathrm{~m}$ a.s.l., was selected. Using a higher altitude would result in a higher estimate of glacier contribution. The minimum 15 December contribution was used as the minimum contribution for the 16 December-14 April period (Table 4). The minimum and maximum annual glacier contribution achieved using this approach were 50 and $94 \%$, respectively. The method, therefore, confirmed that at least half of all streamflow during the study period was supplied by glacier melt $(p<0.05)$.

\subsection{Validity and prominence of our results for water resources in semi-arid, mountanious catchments}

We conclude that $50-90 \%$ of streamflow was supplied by glacier melt in the studied year (see contributions during different periods in Table 4). For a basin with a glacier cover of $11.5 \%$, this contribution is high, compared to published results from glacierised basins in other areas (Jost et al., 2012; Koboltschnig et al., 2008; Stahl and Moore, 2006; Verbunt et al., 2003; Zappa and Kan, 2007). It is also high compared to modelled results of the Juncal basin by Ragettli and Pellicciotti (2012), although the results are difficult to compare as their model was applied during relatively wet years. However, compared to the conclusions drawn from historical meteorological and discharge data, our water balance estimate for a dry year seem reasonable (see Figs. 4 and 5 and subsequent discussion). Further, Gascoin et al. (2011) also found that the glacier contribution to streamflow was substantially larger than the percentage of glacier cover in the Huasco Valley (Chile, $\left.29^{\circ} \mathrm{S}\right)$.

The catchments of the two principal rivers in the region, Aconcagua and Maipo, presently have a glacier cover of $6 \%$ and $8 \%$, respectively (DGA, 2011). Given our results for a basin with $11.5 \%$ glacier cover, the contribution of glacier melt in dry years is most likely substantial for the total water supply in the region. If we assume that the contribution of glacier melt to streamflow is approximately proportionate to glacier cover, our results for the Juncal catchment would suggest that total glacier melt contribution for the Aconcagua and Maipo basins in a dry year could be $30 \%$ of annual streamflow. Pena and Nazarala (1987) suggested glacier melt contributions of ca. $30 \%$ for the Maipo basin during the most intense period of glacier melt (January-February) and $5-17 \%$ during October-December for a year with total 
Table 3. Contribution of glacier melt to streamflow on 15 October and 15 December 2011 according to different interpretations of snow isotope data. The first column shows which line from Fig. 6a has been used for the $\delta^{2} \mathrm{H}$ (snow)/altitude relationship and the second column shows which altitude was chosen for snow in the 15 December mass balance calculation. Thereafter, the input snow $\delta^{2} \mathrm{H}$ values for each scenario and the resulting glacier melt contributions are shown.

\begin{tabular}{ll|rr|rr}
\hline $\begin{array}{l}\text { Altitude/snow } \\
\delta^{2} \mathrm{H} \text { relationship }\end{array}$ & $\begin{array}{l}\text { Altitude used for } \\
\text { snow signal on 15 Dec }\end{array}$ & $\begin{array}{l}\delta^{2} \mathrm{H} \text { (snow) used } \\
\text { in mass balance }\end{array}$ & $\begin{array}{c}\text { Glacier melt contribution } \\
\text { to streamflow (\%) }\end{array}$ \\
\cline { 3 - 5 } & & 15 Oct & 15 Dec & 15 Oct & 15 Dec \\
\hline with outliers & 2600-3000 m a.s.l. (mean) & $-121,6$ & -135.2 & 8 & 71 \\
& 3000 m a.s.l. (regression line) & $-121,6$ & -142.1 & 8 & 88 \\
& 4000 m a.s.l. (regression line) & $-121,6$ & -17.36 & 8 & 97 \\
\hline without outliers & 2600-3000 m a.s.l. (mean) & $-115,3$ & -134.3 & 45 & 62 \\
& 3000 m a.s.l. (regression line) & $-115,3$ & -143.8 & 45 & 90 \\
& 4000 m a.s.l. (regression line) & $-115,3$ & -191.3 & 45 & 98 \\
\hline
\end{tabular}

Table 4. Relative contribution of glacier melt to streamflow in three different periods and during one year. Minimum and maximum contributions were determined using different scenarios, each defining a different snow isotope composition (Method I). In Method II, a 95\% confidence interval was used for determining the isotopic composition of snowmelt and glacier melt.

\begin{tabular}{|c|c|c|c|c|c|}
\hline \multirow[t]{3}{*}{ Period/Date } & \multicolumn{4}{|c|}{ Min and max glacier melt contribution to streamflow (\%) } & \multirow[t]{3}{*}{$\%$ of annual flow } \\
\hline & \multicolumn{2}{|c|}{$\begin{array}{l}\text { Method I: } \\
\text { Using different scenarios (see Table 3) } \\
\text { for the interpretation of } \delta^{2} \mathrm{H} \text { (snow) }\end{array}$} & \multicolumn{2}{|c|}{$\begin{array}{c}\text { Method II: } \\
\text { Using a 95\% confidence interval } \\
\text { for the interpretation of } \delta^{2} \mathrm{H} \text { (snow) }\end{array}$} & \\
\hline & $\min$ & $\max$ & $\min$ & $\max$ & \\
\hline 14 Apr-15 Oct 2011 & 25 & 100 & 25 & 100 & 25 \\
\hline 16 Oct-15 Dec 2011 & 35 & 71 & 35 & 78 & 24 \\
\hline 16 Dec 2011-14 Apr 2012 & 62 & 100 & 69 & 100 & 51 \\
\hline Total & 46 & 92 & 50 & 94 & 100 \\
\hline
\end{tabular}

precipitation similar to 2011. Their study was based on a simple melt model using empirical temperature-radiationstreamflow relationships. Future research integrating various methods, basins, and years of study may explain the difference between our estimation of glacier melt contribution and the results from modelling studies such as those conducted by Pena and Nazarala (1987) and Ragettli and Pellicciotti (2012).

Our study confirms that in the year of study, glacier melt was an extremely important water source, comprising at least a third of streamflow in a region where glacier cover is $<10 \%$. Glacier retreat has been observed in the Central Andes (Rabatel et al., 2011; Rivera et al., 2002): the Juncal Norte glacier exemplifies this well with a retreat of $0.35 \mathrm{~km}^{2}$ (3.5\%) between 1999 and 2006 and much more during the last century (Bown et al., 2008). Considering that long-term losses in glacier melt volumes have been projected (Huss et al., 2008; Pellicciotti et al., 2009), water availability in the studied region and other semi-arid mountainous areas of the world may decrease substantially in future dry years. It should be noted though, that in the next few decades, glacier melt volumes might still be increasing, as predicted for the European Alps (Huss et al., 2008; Huss, 2011).

\section{Conclusions and directions for further research}

In this study of isotope variation in a high-altitude meltdominated Andean catchment, we draw conclusions that complement earlier studies on the subject and add novel information about the hydrology of this environment:

Firstly, although evidence of isotopic elution could be seen in snow data (late-stage snowpack meltwater was isotopically more enriched than pre-melt snowpack), the largest source of isotopic variation in snow was undoubtedly the catchment's altitude gradient, causing a distinct pattern in streamflow isotopic composition. Further research is needed in order to validate and refine this effect in the Andes and other regions.

Secondly, in the studied catchment and year, glacier melt rather than snowmelt was the dominant source of streamflow at all times of high ( $>50 \%$ of peak) 
discharge. For the melt season, snowmelt was unequivocally dominant only during spring (mid-October to midNovember). Long-term decreases in glacier melt volumes due to global warming could therefore result in a dramatic decline in water availability for central Chile, especially in years with low precipitation.

A quantitative analysis of streamflow isotopic variability combined with detailed analysis of its sources such as performed here is a valuable source of information. These results may be compared with and assimilated into hydrological models of varying complexity in order to shed light on the interplay of mechanisms governing flow variability in semiarid, melt-dominated rivers.

A desirable follow up of this research would include the application of stable water isotopes for detailed hydrograph separation on a daily or weekly scale, which require that the following challenges must be addressed:

- We did not observe a difference in the average $\delta^{2} \mathrm{H} / \delta^{18} \mathrm{O}$ ratio of major sources. Other tracers such as hydrochemical data could improve the performance of separation models such as EMMA or Bayesian Mixing models. Adding a full hydrochemical analysis of major solutes would lead to new research questions such as flow routing for the different sources and resulting streamflow (Brown et al., 2006; Cristophersen and Hooper, 1992). Such upcoming research will help us test the flowpaths suggested in Fig. 3.

- The isotopic composition of snowmelt changes with altitude and therefore with time during snowmelt.

- Glacier melt had an isotopic signal between that of lowand high altitude snow, meaning that a mixing model will have substantial problems separating these sources. A more detailed analysis would require data of different types and sources, assimilated into more complex mixing models.

The distinct pattern in the stable water isotope tracer data, observed in the Juncal River during spring to early summer (caused by snowmelt from increasingly higher altitudes and higher contributions of glacier melt) allows for interpretation of snowmelt transit time and connections between catchment hypsometry and discharge variability. Such data collected in comparable rivers and in years with different snow accumulation, combined with SCA and meteorological data, could be an excellent tool for exploring how runoff mechanisms and sources change through the snowmelt season and how they are controlled by catchment geomorphology and snowmelt input from different altitudes. For example, in catchments with similar hypsometry, storage times could be compared using the degree of dampening in the snowmelt isotope pattern (cf. Asano and Uchida, 2012; Lyon et al.,
2010; McGuire and McDonnell, 2006). In catchments without a significant glacier cover, elimination of the glacier signal would help the analysis of transit time and progression of snowmelt.

Acknowledgements. This research was supported by Fondecyt grant No 1121184 and by CONICYT-DRI grant SER-003. The authors wish to thank Daniele Pena, Jacob C. Yde and an anonymous reviewer for their thoughtful comments and constructive criticism to the first draft of this paper.

Edited by: I. van Meerveld

\section{References}

Aravena, R., Suzuki, O., Peña, H., Pollastri, A., Fuenzalida, H. A., and Grilli, A.: Isotopic composition and origin of the precipitation in Northern Chile, Appl. Geochem., 14, 411-422, 1999.

Asano, Y. and Uchida, T.: Flow path depth is the main controller of mean base flow transit times in a mountainous catchment, Water Resour. Res., 48, 1-8, doi:10.1029/2011WR010906, 2012.

Barnes, C. J. and Turner, J. V.: Isotopic exchange in soil water, in: Isotope tracers in catchment hydrology, edited by: Kendall, $\mathrm{C}$. and McDonnell, J. J., Elsevier, Amsterdam, The Netherlands and Oxford, UK, 1998.

Barnett, T. P., Adam, J. C., and Lettenmaier, D. P.: Potential impacts of a warming climate on water availability in snow-dominated regions, Nature, 438, 303-309, doi:10.1038/nature04141, 2005.

Bottomley, D. J., Craig, D., and Johnston, L. M.: Neutralization of acid runoff by groundwater discharge to streams in Canadian Precambrian Shield watersheds, J. Hydrol., 75, 1-26, 1984.

Bown, F., Rivera, A., and Acuña, C.: Recent glacier variations at the Aconcagua basin, central Chilean Andes, Ann. Glaciol., 48, 43-48, doi:10.3189/172756408784700572, 2008.

Brown, L. E., Hannah, D. M., Milner, A. M., Soulsby, C., Hodson, A. J., and Brewer, M. J.: Water source dynamics in a glacierized alpine river basin (Taillon-Gabiétous, French Pyrénées), Water Resour. Res., 42, W08404, doi:10.1029/2005WR004268, 2006.

Cable, J., Ogle, K., and Williams, D.: Contribution of glacier meltwater to streamflow in the Wind River Range, Wyoming, inferred via a Bayesian mixing model applied to isotopic measurements, Hydrol. Process., 25, 2228-2236, doi:10.1002/hyp.7982, 2011.

Cai, X., Rosengrant, M. W., and Claudia, R.: Physical and economic efficiency of water use in the river basin: Implications for efficient water management, Water Resour. Res., 39, WES 1.1-WES 1.12, doi:10.1029/2001WR000748, 2003.

Clark, I. D. and Fritz, D.: Environmental Isotopes in Hydrogeology, Lewis Publishers, New York, USA, 1997.

Cooper, L. W., Solis, C., Kane, D. L., and Hinzman, L. D.: Application of Oxygen-18 Tracer Techniques to Arctic Hydrol. Process, Arctic Alpine Res., 25, 247-255, 1993.

Cortés, G., Vargas, X., and McPhee, J.: Climatic sensitivity of streamflow timing in the extratropical western Andes Cordillera, J. Hydrol., 405, 93-109, doi:10.1016/j.jhydrol.2011.05.013, 2011. 
Cristophersen, N. and Hooper, R. P.: Multivariate analysis of stream water chemical data: the use of Principal Components Analysis for the End-Member mxing problem, Water Resour. Res., 28, 99107, 1992.

Dincer, T., Payne, B. R., Florkowski, T., Martinec, J., and Tongiorgi, E.: Snowmelt runoff from measurements of tritium and oxygen18, Water Resour. Res., 6, 110-124, 1970.

Garreaud, R. D., Vuille, M., Compagnucci, R., and Marengo, J.: Present-day South American climate, Palaeogeogr. Palaeocl., 281, 180-195, doi:10.1016/j.palaeo.2007.10.032, 2009.

Gascoin, S., Kinnard, C., Ponce, R., Lhermitte, S., MacDonell, S., and Rabatel, A.: Glacier contribution to streamflow in two headwaters of the Huasco River, Dry Andes of Chile, The Cryosphere, 5, 1099-1113, doi:10.5194/tc-5-1099-2011, 2011.

Gazis, C. and Feng, X.: A stable isotope study of soil water: evidence for mixing and preferential flow paths, Geoderma, 119, 97-111, doi:10.1016/S0016-7061(03)00243-X, 2004.

Graham, L. P.: Climate change effects on river flow to the Baltic Sea, Ambio, 33, 235-241, 2004.

Huss, M.: Present and future contribution of glacier storage change to runoff from macroscale drainage basins in Europe, Water Resour. Res., 47, 1-14, doi:10.1029/2010WR010299, 2011.

Huss, M., Bauder, A., Funk, M., and Hock, R.: Determination of the seasonal mass balance of four Alpine glaciers since 1865, J. Geophys. Res., 113, 1-11, doi:10.1029/2007JF000803, 2008.

Ingraham, N. L.: Isotopic variation in precipitation, in: Isotope tracers in catchment hydrology, edited by: Kendall, C. and McDonnell, J. J., Elsevier, Amsterdam, The Netherlands and Oxford, UK, 1998.

Jeelani, G., Feddema, J. J., Van der Veen, C. J. and Stearns, L.: Role of snow and glacier melt in controlling river hydrology in Liddar watershed (western Himalaya) under current and future climate, Water Resour. Res., 48, W12508, doi:10.1029/2011WR011590, 2012.

Jost, G., Moore, R. D., Menounos, B., and Wheate, R.: Quantifying the contribution of glacier runoff to streamflow in the upper Columbia River Basin, Canada, Hydrol. Earth Syst. Sci., 16, 849-860, doi:10.5194/hess-16-849-2012, 2012.

Koboltschnig, G. R., Sch, W., Zappa, M., Kroisleitner, C., and Holzmann, H.: Runoff modelling of the glacierized Alpine Upper Salzach basin (Austria): multi-criteria result validation, Hydrol. Process., 3964, 3950-3964, doi:10.1002/hyp.7112, 2008.

Laudon, H.: Hydrological flow paths during snowmelt: Congruence between hydrometric measurements and oxygen 18 in meltwater, soil water, and runoff, Water Resour. Res., 40, 1-9, doi:10.1029/2003WR002455, 2004.

Laudon, H. and Slaymaker, O.: Hydrograph separation using stable isotopes, silica and electrical conductivity: an alpine example, J. Hydrol., 201, 82-101, doi:10.1016/S0022-1694(97)00030-9, 1997.

Lemke, P., Ren, J., Alley, R. B., Allison, I., Carrasco, J., Flato, G., Fujii, Y., Kaser, G., Mote, P., Thomas, R. H., and Zhang, T.: Lemke et al book chapter 2007.pdf.crdownload, in: Observations: change in snow, ice and frozen ground, in: Climate Change, 2007: The Physical Science Basis. Contribution of Working Group I to the Fourth Assessment Report of the Intergovernmental Panel on Climate Change, edited by: Solomon, S. D., Qin, M., Manning, M., Chen, Z., Marquis, M. Averyt, K. B., Tignor, M., and Miller, H. L., Cambridge University Press,
Cambridge, UK, New York, NY, USA, 2007.

Lis, G., Wassenaar, L. I., and Hendry, M. J.: High-precision laser spectroscopy $\mathrm{D} / \mathrm{H}$ and ${ }^{18} \mathrm{O} /{ }^{16} \mathrm{O}$ measurements of microliter natural water samples, Anal. Chem., 80, 287-93, doi:10.1021/ac701716q, 2008.

LP DAAC (NASA Land Processes Distributed Active Archive Center) MODIS Terra/Aqua Snow Cover Daily 500m, USGS/Earth Resources Observation and Science (EROS) Center, Sioux Falls, South Dakota, 2012.

Lyon, S. W., Laudon, H., Seibert, J., Mörth, M., Tetzlaff, D., and Bishop, K. H.: Controls on snowmelt water mean transit times in northern boreal catchments, Hydrol. Process., 24, 1672-1684, doi:10.1002/hyp.7577, 2010.

Masiokas, M., Villalba, R., Luckman, B., Le Quesne, C., and Aravena, J.: Snowpack Variations in the Central Andes of Argentina and Chile, 1951-2005: Large-Scale Atmospheric Influences and Implications for Water Resources in the Region, J. Climate, 19, 6334-6352, 2006.

Mast, M. A., Kendall, C., Campbell, D. H., Clow, D. W., and Back, J.: Determination of hydrologic pathways in an alpine- subalpine basin using isotopic and chemical tracers, Loch Vale Watershed, Colorado, USA, in: Determination of hydrological pathways in an alpine-subalpine basin using isotopic and chemical tracers, 263-270, IAHS Publ. No. 228, 1995.

McCarthy, J. J., Canziani, F. O., Leary, N. A., Dokken, D. J., and White, K. S: Climate Change 2001: Impacts, Adaptation and Vulnerability, Cambridge University Press, Cambridge, UK, 2001.

McGuire, K. J. and McDonnell, J. J.: A review and evaluation of catchment transit time modeling, J. Hydrol., 330, 543-563, doi:10.1016/j.jhydrol.2006.04.020, 2006.

NASA: Reverb ECHO, available at: reverb.echo.nasa.gov/, last access: 12 September 2012.

Pellicciotti, F., Burlando, P., and Van Vliet, K.: Recent trends in precipitation and streamflow in the Aconcagua River Basin, in: Glacier Mass Balance Changes and Meltwater Discharge, IAHS Assembly, 17-38, IAHS Publ. No. 318, Foz do Iguaçu, Brazil, 2005.

Pellicciotti, F., Bauder, A., and Parola, M.: Effect of glaciers on streamflow trends in the Swiss Alps, Water Resour. Res., 46, 116, doi:10.1029/2009WR009039, 2010.

Peña, H. and Nazarala, B.: Snowmelt-runoff simulation model of a central Chile Andean basin with relevant orographic effects, in: Large Scale Effects of Seasonal Snow Cover, IAHS Publ. No. 166, Vancouver, Canada, 1987.

Penna, D., Stenni, B., Šanda, M., Wrede, S., Bogaard, T. A., Gobbi, A., Borga, M., Fischer, B. M. C., Bonazza, M., and Chárová, $\mathrm{Z}$.: On the reproducibility and repeatability of laser absorption spectroscopy measurements for $\delta^{2} \mathrm{H}$ and $\delta^{18} \mathrm{O}$ isotopic analysis, Hydrol. Earth Syst. Sci., 14, 1551-1566, doi:10.5194/hess-141551-2010, 2010.

Penna, D., Stenni, B., Šanda, M., Wrede, S., Bogaard, T. A., Michelini, M., Fischer, B. M. C., Gobbi, A., Mantese, N., Zuecco, G., Borga, M., Bonazza, M., Sobotková, M., Čjková, B., and Wassenaar, L. I.: Technical Note: Evaluation of between-sample memory effects in the analysis of $\delta^{2} \mathrm{H}$ and $\delta^{18} \mathrm{O}$ of water samples measured by laser spectroscopes, Hydrol. Earth Syst. Sci., 16, 3925-3933, doi:10.5194/hess-16-3925-2012, 2012. 
Rabatel, A., Castebrunet, H., Favier, V., Nicholson, L., and Kinnard, C.: Glacier changes in the Pascua-Lama region, Chilean Andes $\left(29^{\circ} \mathrm{S}\right)$ : recent mass balance and $50 \mathrm{yr}$ surface area variations, The Cryosphere, 5, 1029-1041, doi:10.5194/tc-5-10292011, 2011.

Ragettli, S. and Pellicciotti, F.: Calibration of a physically based, spatially distributed hydrological model in a glacierized basin: On the use of knowledge from glaciometeorological processes to constrain model parameters, Water Resour. Res., 48, 1-20, doi:10.1029/2011WR010559, 2012.

Rivera, A., Acuña, C., Casassa, G., and Bown, F.: Use of remotely sensed and field data to estimate the contribution of Chilean glaciers to eustatic sea-level rise, Ann. Glaciol., 34, 367-372, 2002.

Rodhe, A.: Snowmelt-dominated systems, in: Isotope tracers in catchment hydrology, edited by: Kendall, C. and McDonnell, J. J., Elsevier, Amsterdam, The Netherlands and Oxford, UK, 1998.

Rozanski, K. and Araguás, L.: Spatial and temporal variability of stable isotope composition over the South American continent, Bull. Inst. Fr. Etud. Andin., 24, 379-390, 1995.

Rubio-Álvarez, E. and McPhee, J.: Patterns of spatial and temporal variability in streamflow records in south central Chile in the period 1952-2003, Water Resour. Res., 46, 1-16, doi:10.1029/2009WR007982, 2010.

Siegenthaler, U. and Oeschger, H.: Correlation of 180 in precipitation with temperature and altitude, Nature, 285, 314-317, 1980.

Spangenberg, J. E., Dold, B., Vogt, M.-L. and Pfeifer, H.-R.: Stable hydrogen and oxygen isotope composition of waters from mine tailings in different climatic environments, Environ. Sci. Technol., 41, 1870-6, 2007.

Stahl, K. and Moore, R. D.: Influence of watershed glacier coverage on summer streamflow in British Columbia, Canada, Water Resour. Res., 42, 2-6, doi:10.1029/2006WR005022, 2006.
Taylor, S., Feng, X., Kirchner, J. W., Osterhuber, R., Klaue, B., and Renshaw, C. E.: Isotopic evolution of a seasonal snowpack and its melt and became progressively enriched and the dependence can be reproduces the observed progressive, Water Resour. Res., 37, 759-769, 2001.

Unnikrishna, P. V., McDonnell, J. J., and Kendall, C.: Isotope variations in a Sierra Nevada snowpack and their relation to meltwater, J. Hydrol., 260, 38-57, doi:10.1016/S0022-1694(01)00596$0,2002$.

Verbunt, M., Gurtz, J., Jasper, K., Lang, H., Warmerdam, P., and Zappa, M.: The hydrological role of snow and glaciers in alpine river basins and their distributed modeling, J. Hydrol., 282, 3655, doi:10.1016/S0022-1694(03)00251-8, 2003.

Viale, M. and Nuñez, M. N.: Climatology of Winter Orographic Precipitation over the Subtropical Central Andes and Associated Synoptic and Regional Characteristics, J. Hydrometeor., 12, 481-507, doi:10.1175/2010JHM1284.1, 2011.

Viviroli, D., Archer, D. R., Buytaert, W., Fowler, H. J., Greenwood, G. B., Hamlet, A. F., Huang, Y., Koboltschnig, G., Litaor, M. I., López-Moreno, J. I., Lorentz, S., Schädler, B., Schreier, H., Schwaiger, K., Vuille, M., and Woods, R.: Climate change and mountain water resources: overview and recommendations for research, management and policy, Hydrol. Earth Syst. Sci., 15, 471-504, doi:10.5194/hess-15-471-2011, 2011.

Waylen, P. R. and Poveda, G.: Annual and seasonal fluctuations of precipitation and streamflow in the Aconcagua River basin, Chile, J. Hydrol., 120, 79-102, 1990.

Zappa, M. and Kan, C.: Extreme heat and runoff extremes in the Swiss Alps., Nat. Haz. Earth Syst. Sc., 7, 375-389, doi:10.5194/nhess-7-375-2007, 2007. 